\title{
PENGATURAN BIROKRASI APARATUR SIPIL NEGARA YANG NETRAL DAN BEBAS DARI INTERVENSI POLITIK
}

\author{
Anak Agung Adi Lestari, Fakultas Hukum Universitas Mahasaraswati, \\ Email: gungmirah118@gmail.com \\ doi: https://doi.org/10.24843/KS.2020.v08.i12.p09.
}

\begin{abstract}
ABSTRAK
Tujuan pada penelitian ini adalah untuk mengkaji implementasi prinsip netralitas aparatur sipil negara dalam politik sebagaimana Undang-Undang Nomor 5 Tahun 2014 dan menganalisis konsep birokrasi yang netral dan bebas dari intervensi politik bagi Aparatur Sipil Negara. Metode Penelitian menggunkan jenis penelitian hukum normatif. Netralitas Aparatur Sipil Negara sangat dibutuhkan bagi organisasi pemerintahan yang misi utamanya adalah mengatur, melayani dan memberdayakan masyarakat agar terwujud kesejahteraan masyarakat dan Konsep birokrasi yang netral dan bebas dari intervensi politik hendaknya berdasarkan pada kualifikasi Manajemen Aparatur Sipil Negara diselenggarakan berdasarkan Sistem Merit.
\end{abstract}

Kata kunci: Prinsip Netralisasi, Birokrasi, Aparatur Sipil Negara

\section{ABSTRACT}

The purpose of this study is to examine the implementation of the principle of neutrality of the state civil servants in politics as referred to in Law Number 5 of 2014 and to analyze the concept of a bureaucracy that is neutral and free from political intervention for the State Civil Apparatus. The research method uses normative legal research. The neutrality of the State Civil Apparatus is urgently needed for government organizations whose main mission is to regulate, serve and empower the community so that public welfare is realized and the concept of a bureaucracy that is neutral and free from political intervention should be based on the qualifications of State Civil Apparatus Management organized based on the Merit System.

Keywords: Neutralization Principles, Bureaucracy, State Civil Apparatus

\section{PENDAHULUAN}

\subsection{Latar Belakang Masalah}

Negara Indonesia merupakan Negara Hukum (rechtsstaat), bukan negara kekuasaan (machtsstaat). ${ }^{1}$ Paham Negara Hukum tidak dapat dipisahkan dari paham kedaulatan rakyat (demokrasi). ${ }^{2}$ Oleh karena itu, perlu ditegaskan bahwa "kedaulatan berada di tangan rakyat yang dilaksanakan menurut Undang-Undang Dasar" (contitutional democracy)" dengan diimbangi penegasan bahwa Negara Indonesia adalah negara hukum yang berkedaulatan rakyat atau demokratis (demokracy rechtsstaat) dan sekaligus adalah Negara Demokrasi yang berdasarkan atas hukum (constitutional democrasy).

Dengan demikian dalam konsep demokrasi, pemerintahan suatu negara merupakan pemerintahan dari rakyat, oleh rakyat dan untuk rakyat. Keterlibatan rakyat

\footnotetext{
${ }^{1}$ Jimly Asshiddiqie, Konstitusi dan Konstitusionalisme Indonesia, Sinar Grafika, Jakarta, 2011, hal. 57

${ }^{2}$ Matul Huda, Hukum Tata Negara Indonesia, Rajawail Pers, Jakarta, 2013, hal. 267-268
} 
dalam bentuk demokrasi tersebut dilihat pada pelaksanaan Pemilihan Kepala Daerah atau disingkat dengan Pilkada. Berdasarkan pasal 18 ayat (4) Undang-Undang Dasar 1945 Republik Indonesia, Pilkada adalah: "Gubernur, Bupati dan Walikota masingmasing sebagai kepala pemerintahan daerah provinsi, kabupaten dan kota dipilih secara demokrasi".

Pilkada langsung ini mulai diselenggarakan pertama kali di Indonesia pada Bulan Juni 2005 atau sejak berlakunya Undang-Undang Nomor 23 Tahun 2014 tentang perubahan atas UndangUndang Nomor 32 Tahun 2004 Tentang Pemerintahan Daerah. Perubahan tatanan sistem Pilkada dari tidak langsung menjadi langsung diharapkan mampu menjaring calon-calon pemimpin kepala daerah yang berkualitas sesuai dengan keinginan rakyat dan pemimpin yang mementingkan kepentingan rakyat serta dapat terlaksana dengan demokratis. Tetapi hak pilih Aparatur Sipil Negara (selanjutnya disebut ASN) dalam hal tersebut tidak dinyatakan secara terbuka, sehingga cenderung menjadi bentuk "kampanye" yang sifatnya mengarahkan dukungan kepada salah satu pasangan calon. Apalagi kadang kala ASN mudah terbawa arus politik atau dengan kata lain dalam keadaan terpaksa dan mereka tidak netral karena takut di mutasi atau di turunkan jabatan akhirnya mereka memihak kepada salah satu pasangan calon ketika salah satu kandidat merupakan calon pertahana (incumbent).

Pada tahun 2014 untuk mewujudkan reformasi birokrasi, pemerintah mengundangkan Undang-undang Nomor 5 Tahun 2014 tentang Aparatur Sipil Negara. Undang-undang ini menjelaskan dan mempertegas lagi dari netralitas pegawai negeri sipil (selanjutnya disebut PNS) sebagai birokrat yang merupkan bagian dari Negara. Bahkan untuk penyebutan pegawai negeri bukan lagi PNS melainkan ASN yang terdiri dari PNS dan pegawai pemerintah dengan perjanjian kerja (selanjutnya disebut PPPK) Pasal 9 ayat (2) dari Undang-undang ASN mengatakan bahwa : "pegawai ASN harus bebas dari pengaruh dan intervensi semua golongan dan partai politik. Dan dikeluarkannya Undangundang ASN yang mengatur asas netralitas tersebut dapat menghasilkan ASN yang bebas dari intervensi publik. Dimana ASN dalam dunia birokrasi sering dijadikan mesin politik.

Asas netralitas berdasarkan Undang-Undang Nomor 5 Tahun 2014 adalah bahwa setiap Pegawai ASN tidak berpihak dari segala bentuk pengaruh manapun dan tidak memihak kepada kepentingan siapapun. Netralitas dapat juga diartikan dengan bersikap tidak memihak terhadap sesuatu apapun. Dalam konteks ini netralitas diartikan sebagai tidak terlibatnya pegawai negeri sipil atau ikut serta langsung memihak dan mengkampanyekan pemilihan Kepala Daerah, pemilu, dan pilpres baik secara aktif maupun pasif. ${ }^{3}$

Pegawai ASN berada diposisi yang sulit dikarenakan dapat dipakai sebagai suatu alat kepentingan dalam bidang politik. Pada satu sisi mereka ialah pegawai yang diangkat, ditempatkan, dipindahkan dan diberhentikan oleh Pejabat Pembina Kepegawaian (selanjutnya disebut PPK) yang pejabatnya tidak lepas dari unsur politik dikarenakan dari kalangan politik. Dengan demikian karir kerja mereka sering dikaitkan dengan unsur kepentingan politik para PPK. Dilain sisi, para ASN diharuskan bersikap netral dimana untuk menjaga keprofesionalanya dalam menjalankan tugasnya untuk tata kelola kepemerintahan dan dalam pelayanan publik. Dengan hal tersebut ASN dapat

${ }^{3}$ Yamin, , Netralitas Pegawai Negeri Sipil dalam Pemilihan Umum Kepala Daerah di Kabupaten Takalar, Bagian Hukum Tata Negara Fakultas Hukum, Makasar, 2012, hal. 13 
dijadikan suatu alat oleh pejabat politik untuk kepentingannya dalam hal mempertahankan kekuasaanya.

Netralitas ASN menjadi isu yang sering kali mendapat sorotan, dikarenakan banyaknya ditemukan pelanggaran yang dilakukan pegawai ASN mengenai netralitasnya sebagai ASN. Pelanggaran tersebut sering ditemukan seiring dengan menjelangnya pelaksanaan Pilkada. Netralitas ASN akan menjadi suatu isu kedepannya, dikarenakan akan terus adanya penyelenggaraan Pilpres, Pileg ataupun Pilkada. Sementara itu pegawai ASN dituntut akan sikapnya netral dan dapat menjalankan tugasnya secara profesional, dengan demikan penegakan netralitas ASN menjadikan itu sangat penting.

\subsection{Rumusan Masalah}

Berdasarkan uraian permasalahan yang telah penulis kemukakan diatas, maka dapat ditarik rumusan-rumusan permasalahan pokok diantaranya yaitu:

1. Bagaimanakah implementasi prinsip netralitas aparatur sipil negara dalam politik sebagaimana Undang-Undang Nomor 5 Tahun 2014 ?

2. Bagaimanakah konsep birokrasi yang netral dan bebas dari intervensi politik bagi aparatur sipil negara?

\subsection{Tujuan Penelitian}

Tujuan pada penelitian ini adalah untuk mengkaji implementasi prinsip netralitas aparatur sipil negara dalam politik sebagaimana Undang-Undang Nomor 5 Tahun 2014 dan menganalisis konsep birokrasi yang netral dan bebas dari intervensi politik bagi ASN.

\section{METODE PENELITIAN}

Tipe penelitian yang dipergunakan adalah tipe penelitian hukum normatif. Mengenai sumber bahan hukum yang digunakan terbagi atas Bahan Hukum Primer adalah bahan hukum yang utama yang menjadi dasar kajian dari penulisan ini, Bahan Hukum sekunder adalah adalah bahan hukum yang digunakan untuk menunjang atau membantu dalam memberikan pemahaman-pemahaman dan gambaran-gambaran serta teori-teori hukum yang di gunakan untuk mengulas dan memecahkan persoalanpersoalan yang akan di teliti di dalam penelitian penulisan ini. dan Bahan Hukum Tersier adalah bahan hukum yang memberikan petunjuk maupun penjelasan terhadap bahan hukum primer dan sekunder.

Untuk memperoleh bahan-bahan hukum primer, sekunder dan tersier digunakan teknik inventarisasi atau penelusuran bahan hukum yang bersangkutan lalu di klasifikasi atau dikelompokan dan didokumentasikan, dicatat, dikutip, diringkas, diulas sesuai kebutuhan dengan pendekatan kualitatif.

Setelah bahan hukum primer dan bahan hukum sekunder terkumpul, maka bahan hukum tersebut akan diolah dan dianalisis dengan menggunakan metode pengolahan bahan hukum secara sistematis.

\section{HASIL DAN PEMBAHASAN}




\subsection{Implementasi Prinsip Netralitas Aparatur Sipil Negara Dalam Politik Sebagaimana Undang-Undang Nomor 5 Tahun 2014}

Netralitas menurut Kamus Besar Bahasa Indonesia (KBBI) adalah keadaan dan sikap netral, dalam arti tidak memihak, atau bebas. Menurut Nuraida Mokhsen netralitas ASN mengandung makna impartiality yaitu bebas kepentingan, bebas intervensi, bebas pengaruh, adil, objektif, dan tidak memihak. ${ }^{4}$ Sementara itu Marbun dalam Sri Hartini (2009) menyampaikan bahwa netralitas adalah bebasnya Pegawai Negeri Sipil dari pengaruh kepentingan partai politik tertentu atau tidak memihak untuk kepentingan partai politik tertentu atau tidak berperan dalam proses politik. ${ }^{5}$

Netralitas PNS sangat dibutuhkan bagi organisasi pemerintahan yang misi utamanya adalah mengatur, melayani dan memberdayakan masyarakat agar terwujud kesejahteraan masyarakat. Hal ini dapat dilihat sebagai berikut:

a) Pertama, dengan netralitas, PNS tidak lagi terganggu dengan pekerjaan pekerjaan yang diluar tugas dan tanggung jawabnya, sehingga lebih difokus pada pekerjaannya.

b) Kedua, PNS merasa lebih aman bekerja, punya kepastian masa depan dimana tergantung kepada hasil kerja dan prestasi kerjanya, tidak ada lagi faktor-faktor subjektif yang tidak punya standar yang pasti.

c) Ketiga, PNS akan berkompetisi secara sehat dalam menghasilkan prestasi, sehingga akan muncul inovasi baru dalam menyelesaikan suatu persoalan ataupun guna melancarkan penyelenggaraan pemerintahan.

d) pemberian pelayanan akan lebih baik, karena tidak ada lagi sikap yang diskriminatif ataupun adanya intervensi tertentu dalam memberikan pelayanan.

Peraturan yang terkait dengan netralitas dari PNS telah diundangkan dengan beberapa perundang-undangan, yaitu antara lain Undang-Undang Nomor 5 Tahun 2014 tentang Aparatur Sipil Negara, netralitas disini artinya PNS yang sebagai ASN tidak boleh berpihak kepada siapapun juga dalam segala urusan kegiatan politik. Peraturan Pemerintah Nomor 37 Tahun 2004 tentang Larangan Pegawai Negeri Sipil Menjadi Anggota Partai Politik, dalam isi undang-undang ini menyatakan secara tegas akan larangan PNS untuk ikut terlibat segala urusan dalam partai politik, dikarenakan jika PNS terlibat urusan dalam partai politik itu sama saja PNS akan melanggar prinsip netralitasnya. Peraturan Pemerintah Nomor 53 Tahun 2010 tentang Disiplin Pegawai Negeri Sipil disini juga ditegaskan kembali bahwa PNS harus bersikap netral dengan merujuk ketentuan dalam Pasal 3 mengenai kewajiban dan pasal 4 mengenai larangan. Serta Undang-Undang Nomor 8 Tahun 2015 tentang Perubahan Atas Undang-Undang No 1 Tahun 2015 tentang Penetapan Peraturan Pemerintah Pengganti Undang-Undang No 1 Tahun 2014 tentang Pemilihan Gubernur, Bupati Dan Walikota Menjadi Undangundang dalam Pasal 70 ayat (1) yang melarang PNS terlibat dalam kegiatan kampanye calon Kepala Daerah/Wakil Kepala Daerah.

${ }^{4}$ Mokhsen, Nuraida. FGD Sistem Pengawasan KASN Terhadap Pelaksanaan Asas Netralitas ASN, Jakarta, 2018,

${ }^{5}$ Sri Hartini, Penegakan Hukum Netralitas Pegawai Negeri Sipil (PNS), Jurnal Dinamika Hukum Vol. 9, No. 3, 2009. 
Netralitas Aparatur Sipil Negara (ASN) sebagaimana yang tertuang dalam Undang-Undang Nomor 5 Tahun 2014 Tentang ASN pasal 2 huruf f, menyebutkan "Asas penyelenggaraan kebijakan dan manajemen ASN adalah Netralitas" Asas netralitas ini berarti bahwa setiap pengawai ASN tidak berpihak dari segala bentuk pengaruh manapun dan tidak memihak kepada kepentingan siapapun. Hal tersebut dikarenakan netralitas ASN merupakan pilar penting dalam kelangsungan terselenggaranya tata pemerintahan yang baik (good governance). Oleh karena itu, pegawai ASN sebagai unsur aparatur negara yang dapat memberikan pelayanan kepada masyarakat secara profesional, jujur, adil dan merata.

Peran Pegawai ASN sebagaimana yang dimaksud untuk menwujudkan ASN yang bersih dalam upaya menciptapkan good governance. Makna good dalam good governance mengandung 2 (dua) pengertian. Pertama, nilai yang menjunjung tinggi keinginan atau kehendak rakyat, dan nilai yang dapat meningkatkan kemampuan rakyat dalam mencapai tujuan nasional, kemandirian, pembangunan berkelanjutan dan keadilan sosial. Kedua, aspek fungsional dan pemerintah yang efektif dan efisien dalam pelaksanaan tugasnya untuk mencapai tujuan tersebut. Sedangkan untuk makna Governance, World bank mendefinisikan sebagai penyelenggaraaan manajemen pembangunan yang bertanggung jawab, sejalan dengan demokrasi serta pasar yang efisien dan penghindaran salah alokasi dana investasi langkah pencegahan korupsi, baik secara politik maupun administratif serta menjalankan disiplin dengan anggaran serta penciptaan llegal dan political framework. ${ }^{6}$

Namun selama ini ASN tidak bisa bersikap netral, karena mudah terbawa arus politik dan perlu melakukan lobi untuk mendapatkan promosi jabatan. Perbuatan oknum ASN dalam mendukung pasangan calon Kepala Daerah dan Wakil Kepala Daerah menjadi berita sering sekali muncul dalam pemberitaan seputar Pilkada.

Bersikap netral menjelang pesta demokrasi Pilkada, tentu saja tidak ditunjukkan semata pada pejabat yang berencana mencalonkan kembali atau dengan kata lain incumbent. Tapi suatu hal yang harus dipahami seorang ASN mereka harus mampu menempatkan diri sebagai abdi Negara dalam pelayan publik yang profesional dan berkualitas, bukan melayani kepentingan pribadi, kelompok atau calon tertentu. ASN yang bekerja di birokrasi seharusnya lebih ditempatkan sebagai penjaga aturan pemain yang disepakati lewat proses demokrasi. Oleh karena itu, birokrasi seharusnya bersifat netral, bersih, dan profesional.

Pelanggaran-pelanggaran terhadap netralitas ASN dalam tahapan Pilkada di Indonesia sudah lama terjadi, apalagi dalam Pilkada serentak, pemberitaan tentang perlibatan ASN misalnya dalam proses sebelum dan sesudah masa kampanye. Di sisi lain, mereka paham bahwa ada peraturan tegas yang mengharuskan ASN netral dan tidak boleh berpihak pada salah satu pasangan calon Pilkada. Karena apabila mereka (ASN) melanggar peraturan-peraturan tersebut akan dikenakan sanksi sesuai dengan jenis pelanggaran yang mereka (ASN) lakukan.

Pasal (5) ayat (2) UU ASN berisi pengaturan perilaku agar Pegawai ASN; (e) melaksanakan tugasnya sesuai dengan perintah atasan atau pejabat yang berwenang sejauh tidak bertentangan dengan ketentuan perundang-undangan dan etika

${ }^{6}$ Nuryadi dan Tolib, Pendidikan Pancasila dan Kewarganegaraan/Kementrian Pendidikan dan Kebudayaan, Edisi Revisi, Jakarta, 2017. 
pemerintahan, dan (h) menjaga agar tidak terjadi konflik kepentingan dalam melaksankan tugasnya. Namun dalam peraturan pelaksanaannya tidak sejalan dengan ketentuan dengan peraturan pemerintah No. 53 Tahun 2010 tentang Disiplin PNS yakni pasal 3 ayat 5 menyatakan "setiap PNS wajib; melaksanakan tugas kedinasan yang dipercayakan kepada PNS dengan penuh pengabdian, kesadaran, dan tanggung jawab"; dalam penjelasannya menurut ayat tersebut tugas kedinasan yang dimaksud adalah tugas yang diberikan oleh atasan yang berwenang dan berhubungan dengan;

a. perintah kedinasan;

b. peraturan perundang-undangan dibidang kepegwaian atau peraturan yang berkaitan dengan kepegwaian;

c. peraturan kedinasan

d. tata tertib di lingkungan kantor; atau

e. $\quad$ standard prosedur kerja (Standard Operasional Procedur atau SOP)

Kedua ayat dalam UU ASN tersebut memwajibkan bawahan harus melaksanakan segala perintah yang diberikan atasan, apabila tidak melawan ketentuan perundangundangan yang berlaku dan seminim mungkin menimbulkan konflik keperntingan dalam menjalankan tugasnya. Akan tetapi dengan Peraturan Pemerintah Nomor 53 Tahun 2010 tentang disiplin PNS Pasal 3 ayat 5 tidak sejalan. Upaya menjaga kenetralitas bukan sebaliknya diterapkan oleh pimpinan melainkan bawahanlah yang harus menjaga agar tidak terjadi perbedaan sikap yang menimbulkan kerenggangan kepada atasan mengingat tugas kedinasan dilaksanakan dengan penuh pengabdian, kesadaran dan tanggung jawab sebagaimana terkait pasal 3 ayat 5 (PP 53 Tahun 2010). Ini berarti sesorang bawahan tidak dapat mempunyai wewenang lebih pada saat telah di intervensi oleh atasan apabila sudah adanya perintah kedinasan dengan kewenangan yang dimilikinya untuk mengambil langkah pengamanan diluar ketentuan perundangundangan dalam menangani persoalan disiplin PNS dan bawahan diwajibkan unutuk diam.

Apa yang dituangkang dalam Undang-Undang No. 5 Tahun 2014 tentang ASN terkait kenetralitas tidak dapat di tegakan mengingat dan pasal 5 ayat 2, (e) dan (h) menjadi tidak sejalan dengan pasal 3 ayat (5) Peraturan Pemerintah No. 53 Tahun 2010 tentang Disiplin PNS. Dilain pihak seorang bawahan harus dapat menjaga kenetralannya, agar tidak bersinggungan atau menjaga agar tidak terjadi konflik kepentingan dengan atasan dikerenakan posisinya yang taat kepada perintah atasan sehingga tidak dapat melampaui kehendak atasan.

Untuk mewujudkan kenetralitasan setiap pegawai ASN belum sepenuhnya mehami perilakunya dalam organisasi secara baik karena dalam UU ASN terdapat beberapa pasal yang masih menunjukan kesewenang-wenangan atasan dalam pengambilan keputusan.

\subsection{Konsep Birokrasi Yang Netral dan Bebas Dari Intervensi Politik Bagi Aparatur Sipil Negara}

Melalui Undang-Undang No. 5 Tahun 2014 dengan Menajemen ASN diselenggarakan melalui sistem Merit yang berdasarkan pada kualifikasi Manajemen 
ASN diselenggarakan berdasarkan Sistem Merit, yang berdasarkan pada kualifkasi, kompetensi, dan kinerja secara adil dan wajar dengan tanpa membedakan latar belakang poltik, ras, warna kulit, agama, asal- usul, jenis kelamin, status pernikahan, umum, atau kondisi kecacatan. Manajemen ASN ini meliputi Manajemen PNS dan PPPK. Menurut Malthis bahwa pembinaan pegawai adalah suatu kegiatan yang berkaitan dengan peningkatan kecakapan pegawai guna pertumbuhan yang berkesinambungan didalam organisasi.

Lebih lanjut ditambahkan oleh Widjaja pembinaan pegawai adalah segala usaha untuk meningkatkan kemampuan dalam melaksanakan tugas umum pemerintahan dan pembangunan.Dari ketiga defenisi tersebut, jelas bahwa pembinaan pegawai dilaksanakan untuk pertumbuhan dan kesinambungan kualitas pegawai dalam suatu organisasi. ${ }^{7}$ Manfaat dari pembinaan Pegawai Negeri Sipil adalah mewujudkan citra pegawai yang penuh dengan kesetiaan dan ketaatan kepada pancasila, UndangUndang Dasar 1945, Negara dan pemerintah yang bersatu padu, bermental baik, berwibawa, berdaya guna, berhasil guna, bersih, berkualitas tinggi dan sadar akan tanggung jawabnya sebagai unsur aparatur negara, abdi negara dan abdi masyarakat.

Pegawai ASN berfungsi sebagai pelaksana kebijakan publik, pelayan publik, dan perekat dan pemersatu bangsa. Sebagai pelaksana kebijakan publik, Pegawai ASN bertugas untuk melaksanakan kebijakan publik yang dibuat oleh Pejabat Pembina Kepegawaian sesuai dengan ketentuan peraturan perundang-undangan. Sedangkan sebagai pelayan publik, Pegawai ASN bertugas memberikan pelayanan publik yang profesional dan berkualitas, serta mempunyai tugas utama yaitu untuk mempererat persatuan dan kesatuan Negara Kesatuan Republik Indonesia. Disamping menjalankan tugasnya, Pegawai ASN juga berperan sebagai perencana, pelaksana, dan pengawas penyelenggaraan tugas umum pemerintahan dan pembangunan nasional melalui pelaksanaan kebijakan dan pelayanan publik yang profesional, bebas dari intervensi politik, serta bersih dari praktik korupsi, kolusi, dan nepotisme. Frase bebas dari intervensi politik dalam pasal 1 angka (5) mengamanatkan bahwa selaku pegawai ASN dituntut harus dapat terlepas dari segala bentuk pengaruh apapun baik politik atau kepentingan lain yang memaksa kita untuk mengabaikan aturan dan tata laksana yang harus dikedepankan dalam melaksanakan tugas yang diemban dan juga sebagai pegawai ASN dituntun bersikap netral.

Menurut Miftah Thoha, netralitas birokrasi pada hakekatnya adalah suatu sistem di mana birokrasi tidak akan berubah dalam memberikan pelayanan kepada masternya (dari parpol yang memerintah). Lebih lanjut dikatakan bahwa netralitas PNS adalah membuat PNS dalam menjalankan roda administrasi kepemerintahan tidak bergeser walaupun pejabat politik dari parpol yang memerintah itu berubah. ${ }^{8}$

Latar belakang terbentuknya UU ASN adalah sebagaimana dikemukakan sebelumnya bahwa untuk membangun aparatur sipil negara yang tujuannya lebih ditekankan untuk memiliki integritas, profesional, netralitas dan bebas dari intervensi politik, bersih dari praktik korupsi, kolusi dan nepotisme, serta mampu menjalankan peran sebagai unsur perekat persatuan dan kesatuan bangsa dan UUD NRI 1945, maka pemerintah menginginkan sebuah Manajemen yang mengahasilkan pegawai ASN yang

\footnotetext{
${ }^{7}$ Widjaja, A.W, Administrasi Kepegawaian, Rajawali, Jakarta, 1986, hal. 15

${ }^{8}$ Miftah Thoha, Birokrasi dan Politik di Indonesia, PT. Raja Grafindo Persada, Jakarta, 2012, hal. 
diamantakan sesuai pasal 1 ayat 5 sesuai UU ASN yakni Manajemen ASN adalah pengelolaan ASN untuk menghasilkan Pegawai ASN yang professional, memiliki nilai dasar, etika profesi, bebas dari intervensi politik, bersih dari praktik korupsi, kolusi, dan nepotisme. sementara pasal 2 penyelenggaraan kebijakan dan Manajemen ASN berdasarkan 13 asas dan salah satu asas yang harus patut ditegakan dalam pemerintahan yang bebas dari intervensi politik yakni: huruf (f) asas netralitas, yang sangat bertentangan dengan kinerja birokrasi saat ini, karena dijelaskan yang dimaksud dengan "asas netralitas" adalah bahwa setiap Pegawai ASN tidak berpihak dari segala bentuk pengaruh manapun dan tidak memihak kepada kepentingan siapapun.

Dasar ini yang membuat sehingga ketidak stabilan kinerja bawahan dalam melaksanakan tugasnya sebagai penegak disiplin dalam sebuah organisasi jika terjadi penyalahgunaan wewenang dan upaya untuk meloloskan oknum pegawai ASN yang melanggar paraturan disiplin dengan cara yang tidak sesuai prosedur yang berlaku. Max Weber ahli sosiologi Jerman mengembangkan sebuah model struktural yang ia katakan sebagai alat yang paling efisien bagi organisasi-organisasi untuk mencapai tujuannya. Ia menyebut struktur ideal ini sebagai birokrasi. Struktur tersebut dicirikan dengan adanya pembagian kerja, hirarki wewenang yang jelas, prosedur seleksi yang formal, peraturan yang rinci, serta hubungan yang tidak didasarkan pribadi atau impersonal. ${ }^{9}$ Standard Operasional Prosedur telah ditetapkan, hirarki wewenang telah jelas untuk dijalankan namun dalam prosesnya mengalami benturan akibat peraturan yang kurang rinci dan tidak jelas batasan dalam kewenangan-kewengan yang ada masih tejadi penyimpangan. Konsep Max Weber tentang birokrasi berkaitan dengan organisasi rasional, in efisiensi organizational, kekuasaan yang dijalankan oleh pejabat, administrasi negara, administrasi yang dijalankan oleh pejabat, sebuah organisasi, dan masyarakat modern.

UUD NRI 1945 sebagai pedoman landasan dari setiap warga Negara Indonesia kiranya hendak di ilhami kedudukannya sebagai hukum dasar dan hukum tertinggi dari perundang-undangan agar tidak terjadi kesewenang-wenangan dan ketidakadilan dalam sistim pemerintahan oleh karena kepentingan baik oknum ASN maupun akibat faktor in-group.

Melalui peran pemerintah dalam upaya tujuan pembangunan nasional maka perlu juga dilakukan Reformasi birokrasi yang merupakan program prioritas nasional yang dicantumkan sebagai agenda utama pembangunan nasional yang dicanangkan sejak tahun 2010 dalam Rencana Pembangunan Jangka Panjang (RPJP) dan di implementasikan dalam program Rencana Pembangunan Jangka Menengah Nasional $\left(\right.$ RPJMN). ${ }^{10}$

Konsep Tujuan Negara yang dikemukakan oleh Charles E. Merriam dalam uraian mengenai the five mainfuction of the state, mengemukakan ada lima tujuan negara itu bersifat umum, berlaku untuk semua negara termasuk didalamnya negara kesatuan. Kelima tujuan Negara tersebut antara lain :

1. Keamanan (external security)

2. Ketertiban (internal order)

${ }^{9}$ Robbins, Stephen P., Teori Organisasi : Struktur, Desain, dan Aplikasi, Edisi Ketiga, Alih Bahasa Jusuf Udaya, Arcan, Jakarta, 1994.

${ }^{10}$ Fahrii Surayanto, Pelayanan Dan Mekanisme Informasi Publik, Universitas Negeri Semarang, 2013, hal. 39 
3. Keadilan (justice)

4. Kesejateraan (welfare), dan

5. Kebebasan (freedom in varying form).

Kelima tujuan negara tersebut dapat direduksi menjadi kesejahteraan/kemakmuran bersama atau umum.UU ASN telah jelas dikemukakan konsep kenteralan dalam pasalpasal yang telah disebutkan sebelumnya selain itu juga asas-asas dalam UU ASN pasal 2 yang harus di tegakan dan diimplementasikan

\section{KESIMPULAN}

Netralitas PNS sangat dibutuhkan bagi organisasi pemerintahan yang misi utamanya adalah mengatur, melayani dan memberdayakan masyarakat agar terwujud kesejahteraan masyarakat. Namun selama ini ASN tidak bisa bersikap netral, karena mudah terbawa arus politik dan perlu melakukan lobi untuk mendapatkan promosi jabatan. Untuk mewujudkan kenetralitasan setiap pegawai ASN belum sepenuhnya mehami perilakunya dalam organisasi secara baik karena dalam UU ASN terdapat beberapa pasal yang masih menunjukan kesewenang-wenangan atasan dalam pengambilan keputusan.

Konsep birokrasi yang netral dan bebas dari intervensi politik hendaknya berdasarkan pada kualifikasi Manajemen ASN diselenggarakan berdasarkan Sistem Merit, yang berdasarkan pada kualifkasi, kompetensi, dan kinerja secara adil dan wajar dengan tanpa membedakan latar belakang poltik, ras, warna kulit, agama, asal- usul, jenis kelamin, status pernikahan, umum, atau kondisi kecacatan.

Hendaknya adanya revisi regulasi terhadap bentuk pemberian sanksi yang lebih tegas bagi pegawai aparatur sipil Negara yang tidak bersikap netral atau memihak politik, serta adanya pemberian pematangan materi yang lebih mengenai prisip netralisasi bagi aparatur sipil negara sehingga dalam manajemen birokrasi tidak ada lagi intervensi politik agar menjadikan birokrasi yang bersih dari KKN.

\section{DAFTAR PUSTAKA}

Buku

Fahrii Surayanto, Pelayanan Dan Mekanisme Informasi Publik, Universitas Negeri Semarang. 2013.

Jimly Asshiddiqie, Konstitusi dan Konstitusionalisme Indonesia, Sinar Grafika, Jakarta. 2011.

Matul Huda, Hukum Tata Negara Indonesia, Rajawail Pers, Jakarta. 2013.

Miftah Thoha, Birokrasi dan Politik di Indonesia, PT. Raja Grafindo Persada, Jakarta. 2012.

Mokhsen, Nuraida. FGD Sistem Pengawasan KASN Terhadap Pelaksanaan Asas Netralitas ASN, Jakarta. 2018.

Nuryadi dan Tolib, Pendidikan Pancasila dan Kewarganegaraan/Kementrian Pendidikan dan Kebudayaan, Edisi Revisi, Jakarta. 2017. 
Robbins, Stephen P., Teori Organisasi : Struktur, Desain, dan Aplikasi, Edisi Ketiga, Alih Bahasa Jusuf Udaya, Arcan, Jakarta. 1994.

Widjaja, A.W, Administrasi Kepegawaian, Rajawali, Jakarta. 1986,

Yamin, Netralitas Pegawai Negeri Sipil dalam Pemilihan Umum Kepala Daerah di Kabupaten Takalar, Bagian Hukum Tata Negara Fakultas Hukum, Makasar. 2012,

\section{Jurnal}

Sri Hartini, Penegakan Hukum Netralitas Pegawai Negeri Sipil (PNS), Jurnal Dinamika Hukum Vol. 9, No. 3, 2009.

\section{Peraturan Perundangan}

Undang-Undang Dasar 1945 Republik Indonesia

Undang-undang Nomor 5 Tahun 2014 tentang Aparatur Sipil Negara.

Undang-Undang Nomor 23 Tahun 2014 tentang perubahan atas UndangUndang Nomor 32 Tahun 2004 Tentang Pemerintahan Daerah.

Undang-Undang Nomor 8 Tahun 2015 tentang Perubahan Atas Undang-Undang No 1 Tahun 2015 tentang Penetapan Peraturan Pemerintah Pengganti Undang-Undang No 1 Tahun 2014 tentang Pemilihan Gubernur, Bupati Dan Walikota Menjadi Undang-undang 